\title{
The institution of the examining magistrate in the Second Polish Republic*
}

I. Discussions pertaining to the model of criminal procedure, especially its preliminary phase, have been taking place in Poland in recent years. The discussions are, among others, about proposals which concern changes aimed at creating a broader scope of court control over the preliminary procedure. The possibility and validity of introducing the institution of the examining magistrate, in one form or another, or rather reinstating it as it existed in Poland in the past, is under consideration. It does not probably mean a return to the $19^{\text {th }}$ century concept of a magistrate conducting an inquiry but rather it refers to a concept of the court or of the judge for the preliminary procedure, who would be appointed to carry out and control the steps undertaken in its course. The discussion pertaining to the changes of the model of the preliminary procedure, and especially reinstating the institution of the examining magistrate, is also accompanied by a revitalization of professional writing concerning this subject matter. A number of interesting publications on this topic have appeared in recent times. ${ }^{1}$

* Original version: M. Materniak-Pawłowska, Instytucja sędziego śledczego w II Rzeczypospolitej, „Czasopismo Prawno-Historyczne” 2013, Vol. LXV, issue 2.

${ }^{1}$ K. Eichstaedt, Rola sądu w postępowaniu przygotowawczym a instytucja sędziego śledczego [The role of the court in the preliminary procedure and the institution of the examining magistrate], Warsaw 2009; C. Kulesza, Sędzia śledczy w modelu postepowania przygotowawczego na tle prawnoporównawczym [The examining magistrate in the model of the preliminary procedure against the comparative and legal backdrop], Białystok 1991; idem, Sędzia śledczy we wspótczesnym procesie karnym (na tle prawnoporównawczym) [The examining magistrate in the contemporary criminal procedure (against the comparative and legal backdrop)], "Państwo i Prawo" [The State and the Law] 2008, issue 7, p. 20 et seq.; P. Kruszyński, M. Warchoł, Pozycja sędziego śledczego na tle modeli postępowania przygotowawczego [The position of the examining magistrate against the backdrop of the models of the preliminary procedure] (Part 1), "Palestra" [The Bar] 
Consequently, it seems valid to present the model of this institution in greater detail from the moment it appeared on Polish territories during the period of the Partitions of Poland until it was abolished in the Stalinist era. However, the most important point of reference to contemporary times is the interwar period. It is especially salient as, due to the changing legislation, this institution was evolving and assuming different forms. For this reason, it is worthwhile to take a closer look at these solutions but also - which is equally interesting - to present the views of lawyers of that time - theoreticians and practitioners - concerning the usefulness of its existence, the scope of its duties as well as its relation to other organs which took part in the preliminary procedure, namely the public prosecutor's office and the state police of the interwar period.

The legal regulations concerning the examining magistrate which were in force during the interwar period are presented first. Among them are both the post-partitioning provisions which were initially in force and different in relation to particular areas of the state as well as the uniform regulations of the Polish legislator which were introduced in the second decade of the interwar period. Due to the fact that the subject matter concerning the examining magistrate is not homogenous, there are the regulations included in the criminal procedure on the one hand and the provisions pertaining to the system of the judiciary on the other. The former delineate the position of the examining magistrate in the procedure, especially the scope of their competence in the preliminary procedure as well as their relation to other organs which were taking part in it. The latter regulate the status of the magistrate: the method of appointment, the rights and duties of the magistrates, the rules of practicing the profession. Only an analysis of both the elements

2008, No. 3-4, p. 49 et seq as well as (Part 2) No. 5-6, p. 44 et seq.; J. Tylman, Uwagi o modelu postepowania przygotowawczego [Remarks concerning the model of the preliminary procedure] [in:] P. Hofmański (ed.), Węzłowe problemy procesu karnego [The key problems of the criminal procedure], Warsaw 2010, p. 91 et seq.; T. Grzegorczyk, Kilka refleksji na temat sugestii wprowadzenia instytucji sędziego śledczego [Several remarks concerning the suggestion to introduce the institution of the examining magistrate] [in:] P. Hofmański (ed.), Węzłowe problemy... [The key problems...], p. 105 et seq.; P. Kruszyński, M. Warchoł, Sędzia śledczy. Argumenty za i przeciw [The examining magistrate. Arguments for and against] [in:] P. Hofmański (ed.), Węzłowe problemy... [The key problems...], p. 115 et seq.; C. Kulesza, Sędzia śledczy na tle zmian europejskich modeli postepowania przygotowawczego [The examining magistrate against the backdrop of the changes in the European models of the preliminary procedure] [in:] P. Hofmański (ed.), Węzłowe problemy... [The key problems...], p. 124 et seq.; R.A. Stefański, Krytycznie o obecnym modelu postepowania przygotowawczego [Critically about the present model of the preliminary procedure] [in:] P. Hofmański (ed.), Węzłowe problemy... [The key problems...], p. 146 et seq.; M. Kościelniak-Marszał, Sędzia śledczy w ujęciu prawno-historycznym [The examining magistrate according to the legal and historical approach] [in:] P. Hofmański (ed.), Węzłowe problemy... [The key problems...], p. 167 et seq. 
mentioned above can give a complete picture of this institution. A presentation of the most frequently expressed opinions pertaining to the essence, significance, and the position of the examining magistrate follows afterwards.

II. The institution of the examining magistrate appeared for the first time in the European criminal procedure in the $19^{\text {th }}$ century. It is a well-known fact that this institution's model shape was created in Napoleonic France by virtue of the Code of criminal procedure (Code d'instruction criminelle) of 1808. However, its prototype can be found in a much earlier text, namely in a decree by Francis I of 1522. It was known back then as lieutenant criminel who was appointed to conduct inquiries and, simultaneously, to pass judgements (with the assistance of assessors). The Napoleonic Code of criminal procedure divided the procedure into two phases: the preliminary one and the main phase. The first phase was left in the hands of prosecutors and examining magistrates. The former were vested with the power to prosecute crimes and to launch inquiries, while the latter were vested with the power to conduct inquiries for the first time. This last power was obligatory in case of felonies and it was facultative in case of offences. ${ }^{2}$ The idea which was the guiding light for the creators of this institution was to ensure a solid and properly justified indictment, which was in turn supposed to prevent a reckless initiation of proceedings. The task of an examining magistrate was supposed to be not only to collect evidence of the crime which would incriminate a suspect and provide a basis for drawing up an indictment. It was also supposed to protect the people who did not commit criminal acts provided nothing indicated it in the course of the inquiry. The examining magistrate was supposed to constitute a better guarantee of the protection of an individual's rights in the criminal procedure thanks to their independence in comparison with a dependent prosecutor who could be dismissed from office. ${ }^{3}$ This model was gradually adopted in the majority of European countries; however, it was sometimes modified. The institution of the examining magistrate first appeared on Polish territories in the second half of the $19^{\text {th }}$ century. What is more, it happened almost simultaneously on every partitioned land: in 1873 in the Austrian Partition, in 1876 in the Russian Partition, and in 1877 in the Prussian Partition. Naturally, it took place as a result of the legislation of the partitioning states even though it could have happened much earlier.

${ }^{2}$ S. Waltoś, Sędzia śledczy - rys historyczny [The examining magistrate - a historical outline] [in:] Nowy model postępowania przygotowawczego - sędzia śledczy. Konferencja. Warszawa 22 marca $2010 r$. [A new model of the preliminary procedure - the examining magistrate. A conference. Warsaw, the $22^{\text {nd }}$ of March 2010], Warsaw 2010, pp. 16-17.

${ }^{3}$ W. Nestorowicz, Stanowisko sędziego śledczego u nas i na Zachodzie [The position of the examining magistrate in Poland and in the West], "Głos Sądownictwa" [The Voice of the Judiciary] 1932, issue 3, pp. 206-207. 
It nearly happened in the Duchy of Warsaw period when Feliks Łubieński, the Minister of Justice, strived to introduce the Napoleonic procedure there. However, in the end, he was unsuccessful.

1. In the Austrian Partition, an already crystallized institution was brought about by the Austrian criminal procedure law of the $23^{\text {rd }}$ of May $1873 .{ }^{4}$ It was in force on Polish territories not only until independence was regained but also in the first decade of the existence of the Second Polish Republic. It was replaced by the uniform Code of Criminal Procedure when it came into force on the $1^{\text {st }}$ of July 1929. It underwent numerous changes and it was supplemented many times during this period which lasted for more than fifty years. Initially, the changes were made by the Austrian legislator and later they were introduced by the Polish legislator. However, these changes did not pertain to the institution of the examining magistrate, which had been created by the Austrian legislation, and it remained in its original shape until the very end.

The scope of activity of examining magistrates was limited to the district courts, which were called first instance tribunals in the Austro-Hungarian Empire period. They were appointed by the president of the judges of this court and the position was given to one or to several persons ( $§ 11$ of the Austrian Code of Criminal Procedure). Their status was analogous to the status of other judges who adjudicated in the district courts. ${ }^{5}$ Even though examining magistrates were not appointed in other courts, neither in county courts nor in appeal courts (previously called second instance tribunals), not to mention the Supreme Court, however, similar procedural powers were also granted in certain circumstances to the county courts.

The role of the examining magistrate was mainly connected with the preliminary procedure which took the form of a preliminary investigation or of an initial inquiry. The preliminary investigation included initial court proceedings (for instance, interrogations of persons, the examination of a crime scene) which were undertaken upon the motion of the prosecution or, in special circumstances, without such a motion ( $\S 88$ and 89 of the Austrian Code of Criminal Procedure). Prosecutors could demand the proceedings to be carried out by examining magistrates, county courts, or the police. In matters of great urgency, examining magistrates, and county courts in particular, which did not have a prosecutor in their seat, had the right to independently undertake court proceedings which were included in the scope of the preliminary procedure. However, they were obliged to No. 119.

4 "Reichsgesetzblatt für die im Reichrat(h)e vertretenen Königreiche und Länder" 1873,

${ }^{5}$ M. Materniak-Pawłowska, Ustrój sądownictwa powszechnego w II Rzeczypospolitej [The system of common courts in the Second Polish Republic], Poznań 2003, pp. 117-121. 
inform the prosecutor of this fact. Examining magistrates, as well as county judges, who conducted activities in the course of the preliminary procedure entered the scope of powers of judges carrying out initial inquiries ( $\S 88$ of the Austrian Code of Criminal Procedure). After the preliminary investigation was completed, it was the magistrate's duty to send the minutes of the undertaken activities to the prosecutor. In turn, the prosecutor made a decision regarding the further fate of the procedure. They could decide to refrain from further action if there were no grounds for it in the prosecutor's opinion. Alternatively, they could transfer the case for an initial inquiry or to press charges straight away ( $\S 90$ of the Austrian Code of Criminal Procedure). The initial inquiry could only commence upon the prosecutor's motion and it took place in case of a specific suspect. Its aim was to establish whether a satisfactory premise existed in order to prepare an indictment or to refrain from further proceedings. It was obligatory in case of felonies, which were under the jurisdiction of jury trials as well as during in absentia cases ( $§ 91$ of the Austrian Code of Criminal Procedure). Conducting an initial inquiry was in the purview of examining magistrates who were independent in this area and unbound by further motions of the prosecution. However, they remained under the supervision of a special three-person department of a given district court. It was appointed at the beginning of each year and it was called an Advisory Chamber ( $\$ 12$ of the Austrian Code of Criminal Procedure). This institution, which had its roots in the French system but was significantly modified by the Austrian legislation, occupied a superior position in relation to examining magistrates. This position was highlighted in numerous issues, for example: examining magistrates had to acquire a resolution of the Advisory Chamber in order to reject a motion to commence an initial inquiry made by the prosecution ( $\$ 92$ of the Austrian Code of Criminal Procedure) or to refrain from an initial inquiry without the prosecutor's consent ( $\$ 109$ of the Austrian Code of Criminal Procedure); examining magistrates had the duty to make a report concerning the state of the ongoing initial inquiries to the Advisory Chamber at least once a month ( $§ 94$ of the Austrian Code of Criminal Procedure); unsatisfied parties could make a complaint against each and every resolution of examining magistrates or delays on their part to the Advisory Chamber ( $§ 113$ of the Austrian Code of Criminal Procedure). ${ }^{6}$ Moreover, the Advisory Chamber also had the right, in special cases, to transfer initial inquiries in full or in part to the county court which was located in the district ( $§ 12$ of the Austrian Code of Criminal Procedure). If the law provided for complaints

${ }^{6}$ E. Krzymuski, Wyktad procesu karnego ze stanowiska nauki i prawa obowiazujacego $w$ b. dzielnicy austriackiej oraz z uwzględnieniem ważniejszych różnic na innych ziemiach polskich [The lecture on the criminal procedure from the position of the science and law in force in the former Austrian district and factoring in the more important differences on other Polish territories], Cracow 1922, pp. 48-49. 
against the resolutions of the Advisory Chamber, then they were adjudicated by the competent court of appeal. The course of an initial inquiry itself as well as its scope depended on the plan made by an examining magistrate. The law did not restrain them in this sphere by any provisions. They conducted inquiries personally and independently of the prosecutor whose motions bound them only to the extent that rejecting motions required a decision of the Advisory Chamber. The criminal procedure law expressly stipulated that no inquiry actions could be carried out by the prosecutor and they were under pain of being null and void. However, it was possible to entrust certain activities which were part of the inquiry to the county court, both to courts which were within the district as well as to those which were outside the district of a given district court ( $\$ 93$ of the Austrian Code of Criminal Procedure). Neither the prosecutor nor the defence counsel could participate in the formal interrogation of the suspect or witnesses. However, they could take part in such activities as the examination of a crime scene or even indicate objects which in their opinion should have been included in the acts of inquiry. The decisions concerning ending an inquiry were also left at the discretion of examining magistrates even though there were some restrictions in this area. It was their completely independent decision to close an inquiry in a situation in which they decided that it provided a sufficient basis for the prosecution to draft an indictment against a suspect ( $\S 111$ of the Austrian Code of Criminal Procedure). However, the decision to refrain from an inquiry, if it did not provide a basis for drawing up an indictment, was made by a magistrate upon the motion of the prosecution or with the prosecutor's consent. And, in case of absence of either, it required the consent of the Advisory Chamber ( $§ 109$ of the Austrian Code of Criminal Procedure).

2. In the Prussian Partition, the institution of the examining magistrate was mainly regulated by two legal acts from 1877: the judiciary act $^{7}$ as well as the criminal procedure act. ${ }^{8}$ Both legal acts underwent changes and they were supplemented by the German legislator. After Poland regained its independence, they were in force for ten more years and they underwent more changes and they were supplemented by the Polish legislator as well. Some of these changes pertained to the institution of the examining magistrate. ${ }^{9}$

7 The Judiciary act ("Reichs-Gesetzblatt" 1877, No. 4, pp. 41-80).

8 The criminal procedure act ("Reichs-Gesetzblatt" 1877).

${ }^{9}$ Among others: the regulation on the organization of the courts in the former Prussian district ("Tygodnik Urzędowy" [Official Weekly] 1919, issue 70, p. 410). See: Postępowanie karne obowiązujace na ziemiach zachodnich Rzeczypospolitej Polskiej. Zbiór ustaw i rozporzadzeń dotyczqcych ustroju sadownictwa i procesu karnego z orzecznictwem Sadu Najwyższego [The criminal procedure in force in the western territories of the Republic of Poland. A set of acts and regulations concerning the judiciary and the criminal procedure with the judicial decisions of the Supreme Court], compiled by J. Kałużniacki, R.A. Leżański, Warsaw - Poznań 1926, pp. 342. 
As a rule, examining magistrates also functioned only at the district courts. In contrast to other common court judges who were nominated by the President of the Second Polish Republic, examining magistrates (similarly to justices of the peace) were appointed by the Minister of Justice. Moreover, they were appointed for a specified period of time, i.e. for one administrative year ( $\$ 60$ of the German judiciary act). Furthermore, in accordance with the order of the president of the court, they could still conduct the inquiries which they had started earlier after this time elapsed ( $\$ 64$ of the German judiciary act). Examining magistrates were members of the district courts and their status did not vary from the status of the remaining judges. In special circumstances, the activities belonging to examining magistrates could also have been undertaken by county judges or by justices of the peace.

The role of the examining magistrate was also mainly restricted to conducting initial inquiries, which was the second, beside the preliminary investigation, phase of the preliminary procedure. It was only obligatory in cases concerning felonies as well as criminal cases which belonged to the jurisdiction of the district courts and in which the motion to initiate inquiries was made by the prosecution or by the suspect, who produced significant reasons justifying such a need ( $\$ 176$ of the German criminal procedure act). Prosecuting crimes belonged in this territory mainly to the prosecution which was independent of courts. Moreover, the prosecution had the duty to undertake action in case of any suspicion regarding acts which had been committed and which were subject to punishments ( $\$ 152$ of the German criminal procedure act). However, prosecuting crimes also belonged to the police to a certain extent ( $§ 156$ of the German criminal procedure act). During the preliminary investigation, it was the duty of the prosecution to examine the circumstances of a case and make a final decision whether making an indictment which initiated an inquiry was valid. To this end, it could demand an explanation from all public authorities; it also could undertake action by itself (with the exception of interrogations under oath) or it could order the authorities, officers of the police service ( $\S 159$ of the German criminal procedure act) and courts ( $§ 160$ of the German criminal procedure act) to carry out the action. In case of the latter, it was possible to commission particular actions not only to examining magistrates who worked in the district courts but also to county judges or to justices of the peace. In justified cases, when a delay endangered the case, county judges or justices of the peace could undertake the necessary acts of inquiry ex officio ( $§ 163$ of the German criminal procedure act). In such situations, the way they proceeded was regulated by the legal provisions pertaining to the inquiry. After an investigation was completed and when the prosecution considered that there were sufficient grounds to make an indictment, they could make a petition to launch an initial inquiry. Alternatively, the prosecution made a petition directly to the court with an 
indictment (with the exception of cases in which an inquiry was obligatory) or it could order an ex officio discontinuation of the proceedings ( $\$ 168$ of the German criminal procedure act). In contrast to Austria, the German criminal procedure did not provide for an investigation to be carried out by the courts. The investigation was carried out completely by a prosecutor who could commission judges to carry out certain actions.

Similarly to the Austrian Partition, an inquiry could only commence upon the motion of the prosecution ( $\S 152$ of the German criminal procedure act). Such a motion could have been rejected by a court resolution ${ }^{10}$ but only due to a lack of the jurisdiction of the court, inadmissibility of criminal prosecution or inadmissibility of an inquiry in a given case, or in a situation in which the crime in the motion did not fall within the scope of any criminal provisions. An inquiry was conducted against a specific suspect regarding a specific charge against them ( $§ 177$ of the German criminal procedure act). It was also possible to combine criminal cases, by virtue of a court resolution, which remained in connection to each other ( $\S 4$ of the German criminal procedure act). An initial inquiry was conducted personally by an examining magistrate, however, in order to conduct respective acts of inquiry, they could summon county judges. Moreover, upon the motion of the prosecution and by virtue of a county court resolution, it was even possible to transfer the inquiry completely to a county judge ( $\$ 183$ of the German criminal procedure act). Acts of inquiry consisted, among others, in: interrogating suspects, witnesses, and expert witnesses; making examinations; issuing arrest warrants; and overruling arrest warrants with the consent of the prosecution. The prosecution had the right to access the inquiry records, learn of an inquiry's status as well as to make such motions as the prosecution saw fit ( $\$ 194$ of the German criminal procedure act). However, complying with these motions was not obligatory for examining magistrates because the district court was the last instance. Examining magistrates made decisions concerning ending an inquiry and they sent case files to the prosecution. The prosecution could petition for the initial inquiry to be supplemented or bring an indictment to the court with local jurisdiction. The petition to supplement the inquiry also did not absolutely bind the magistrate as the final decision in this situation lay with the district court, not with the prosecution. If there were no grounds to bring an indictment forward, then the district court made a decision to discontinue proceedings ( $\$ 196$ of the German criminal procedure act). The powers of the district courts resulted from $\S 204$ of the Ger-

${ }^{10}$ In accordance with $\S 72$ of the German judiciary act, all decisions concerning initial inquiries, which according to the provisions of the criminal procedure were issued by the court, belonged to the criminal chambers of this court. In particular, the criminal chambers made decisions concerning appeals against the orders of an examining magistrate and also against the orders of a county judge and a justice of the peace who carried out acts of inquiry. 
man criminal procedure act and by its virtue no motions made by the prosecution were binding for the district courts. ${ }^{11}$ An examining magistrate who conducted an inquiry was excluded from adjudicating in a given case by virtue of the act, which meant that they could not participate in the latter stages of the proceedings ( $§ 23$ of the German criminal procedure act). In the former Prussian Partition, there was definitely no excess of the prosecution's powers in relation to the powers of an examining magistrate.

3. In the Russian Partition territories, the institution of the examining magistrate was introduced on the basis of the judicial reform of 1864, which was in force in the Kingdom of Poland, with certain changes, since 1876. A part of this reform was the criminal procedure act as well as the judiciary act. On the territories of the Kingdom of Poland, namely in the contemporary Government General of Warsaw and the Government General of Lublin, the hitherto structure of the Russian judiciary was replaced with a new one in the form of the judiciary of the Kingdom of Poland in 1917 thanks to the efforts of the Department of Justice of the Provisional Council of State. ${ }^{12}$ Moreover, changes were made concomitantly in the Russian criminal procedure and it was also supplemented by issuing transitory provisions to it. ${ }^{13}$ The changes pertained to the examining magistrate among others. After Poland regained its independence, regulations concerning both the system as well as the procedure underwent further amendments, which referred to this institution to a certain extent. ${ }^{14}$

In light of the provisions of the Russian judiciary of 1864, which was introduced in the Kingdom of Poland in 1876, the examining magistrate was called a court trier (Russian sudiebnyj sledowatiel). ${ }^{15}$ They worked at the district courts but they

${ }^{11}$ W. Nestorowicz, Stanowisko sędziego śledczego... [The position of the examining magistrate...], p. 147.

${ }_{12}$ Przepisy tymczasowe o urządzeniu sądownictwa w Królestwie Polskim [Provisional provisions concerning the organization of the judiciary in the Kingdom of Poland] (The Official Journal of the Department of Justice of the Provisional Council of State of the $19^{\text {th }}$ of August 1927, No. 1, Section I, item 1). See more about this subject matter in: M. Materniak-Pawłowska, Ustrój sądownictwa powszechnego... [The organization of the common courts...], pp. 73-75.

${ }_{13}$ Przepisy przechodnie do ustawy postępowania karnego [The transitory provisions for the criminal procedure act] (The Official Journal of the Department of Justice of the Provisional Council of State of the $19^{\text {th }}$ of August 1927, No. 1, Section I, item 4).

${ }^{14}$ Crucially important changes were introduced by virtue of the act of the $25^{\text {th }}$ of February 1921 concerning the changes in the criminal legislation in force in the former Russian Partition (Journal of Laws 1921, No. 30, item 169). Prosecutorial investigations were introduced then.

${ }^{15}$ Article 6 of the Court Organization [in:] Ustawy sadowe obowiazujace w Guberniach Królestwa Polskiego na mocy najwyżej zatwierdzonego 19 lutego 1875 roku postanowienia o zastosowaniu ustaw sadowych z 20 listopada 1864 roku do warszawskiego Okregu Sądowego [Judicial acts in force in the Governorates of the Kingdom of Poland by virtue of the supremely authorized decision of the $19^{\text {th }}$ February 1875 concerning the appliciation of the judicial acts of the $20^{\text {th }}$ of 
were not considered the courts' members and they did not participate in the general court assemblies. They were assigned a special district which was called an inquiry borough. The Minister of Justice had the right to appoint one of the triers working in a given district court to conduct particular inquiries in especially important cases (articles 79-80 of the Russian judiciary). Not only people who fulfilled the necessary requirements to perform the duties of a judge but also court trainees could be appointed as triers provided they exhibited "wystarczającą wiedzą i praktyką w prowadzeniu śledztw" [sufficient knowledge and practice in conducting inquiries] (article 205 of the Russian judiciary). The term "trier" disappeared from Polish provisions which constructed the judiciary of the Kingdom of Poland and it was substituted with the term "examining magistrate." Their position also slightly changed. Since then, they functioned in district courts as one of its judges even though their status was not exactly the same as of the others. The differences pertained, inter alia, to their emolument because examining magistrates were classified into a different pay category than the judges of district courts. However, they could be appointed to complete an adjudication panel, if it was necessary, by the decision of the president of the court. Naturally, however, they could not participate in the adjudication of the cases in which they had conducted the inquiries earlier. ${ }^{16}$

Examining magistrates performed their duties in their allotted districts (previously called boroughs) and they could only perform them on the area of a different precinct in emergencies. The districts were established and abolished by the Minister of Justice, who also issued orders concerning changing their borders.

The local provisions also regulated the practical, or more precisely the technical, side of performing the duties of an examining magistrate. In their light, one could say that examining magistrates had their own law firms at their disposal and they had the responsibility to be on duty there during the hours they determined themselves. Court trainees could be delegated to help them and they had the same rights at their disposal as well as duties as an examining magistrate in certain cases. Examining magistrates had to present information on case movement in their districts to their respective district courts as well as to the prosecution. ${ }^{17}$

In respect to the preliminary procedure, the procedure in Russia was characterized by a large independence of the court and a highly limited role of the

\footnotetext{
November 1864 to the Warsaw District Court], Vol. I: Organizacja sadowa i ustawa notarialna [Organization of the judiciary and the notary act], Saint Petersburg 1875, p. 5.

${ }^{16}$ Article 6 Provisional provisions concerning the organization of the judiciary in the Kingdom of Poland.

${ }^{17}$ Articles 67-75, Tymczasowa Instrukcja Ogólna dla sądów Królestwa Polskiego [Provisional General Instruction for the courts of the Kingdom of Poland] (The Official Journal of the Department of Justice of the Provisional Council of State of the Kingdom of Poland of 1917, No. 2, Section III, item 4).
} 
prosecution, which was frequently reduced to supervision. Investigations were carried out by the police authorities, while inquiries were carried out by examining magistrates. An inquiry was obligatory in case of felonies and offences punished by a prison sentence, ${ }^{18}$ and later it was only obligatory in case of felonies. Its initiation was only possible upon the motion of the prosecution or on the personal initiative of an examining magistrate. In the latter case, it could concern situations in which the examining magistrates themselves had knowledge of a committed crime themselves or if a notification was made by the police, offices, or the perpetrators themselves (article 297 of the Russian criminal procedure). Examining magistrates could also independently decide that a case did not belong to the jurisdiction of a given district court and send the case files back as well as limit themselves to informing the prosecution (article 482 of the Russian criminal procedure). An extraordinary restriction of the prosecutor's powers in relation to the court was a lack of the possibility to discontinue or suspend an inquiry by them due to its groundlessness or other legal reasons (article 518 of the Russian criminal procedure). They only had the possibility to make a proper motion to a district court and, in case the court did not express its consent to refrain from continuing an inquiry, the case was adjudicated by a court of appeal. This issue looked different in the Austrian-German procedure, as according to the adversarial principle of law, if the prosecution rescinded a complaint, then the procedure was discontinued. ${ }^{19}$

In the course of conducting an inquiry, examining magistrates had considerable latitude. In relation to collecting evidence, one interesting construction deserves attention, namely the so-called community interview. Its purpose was to "naświetlenie wartości moralnej" [shed the light on the moral value] of a suspect on the basis of the interrogation of the witnesses (articles 457-460 of the Russian criminal procedure). Admittedly, the prosecution had the inquiry under constant supervision and they could put forward various motions. However, the motions did not infringe upon the independence of the examining magistrates. The magistrates themselves were controlled by the district courts, while the courts were under the control of the courts of appeal.

III. At the end of the 20s, the hitherto mosaic of provisions concerning the judiciary and the criminal procedure was replaced by a uniform law. In relation to the institution under discussion here, essential changes took place. Examining

\footnotetext{
${ }^{18}$ Article 8 The transitory provisions for the criminal procedure act.

19 J. Makarewicz, Procedura karna dla Królestwa Polskiego [The criminal procedure for the Kingdom of Poland], "Przegląd Prawa i Administracji" [The Law and Administration Review] 1918, p. 195.
} 
magistrates possessed wide powers and their position was mainly independent in the course of the preliminary procedure till then, however, restrictions imposed on their powers and position were growing more and more.

The uniform law on the system of common courts of 1928 included not only the institution of the examining magistrate hitherto appointed in each district court but also the institution of the examining magistrate for cases of exceptional importance who was appointed in the court of appeal..$^{20}$ The institution of the examining magistrate for cases of exceptional importance was introduced on the territory of the entire state in 1927 by virtue of the regulation by the President of the Republic of Poland. ${ }^{21}$ Examining magistrates for cases of exceptional importance were appointed in the seat of the court of appeal and the scope of their activity included this whole court's area. The decision concerning the validity of their appointment in a given court of appeal as well as their number belonged to the Minister of Justice. They were appointed by the President of the Republic of Poland upon the advice made by the Council of Ministers enacted on the initiative of the Minister of Justice (later, after the amendments introduced by the regulation of the $7^{\text {th }}$ of October 1932, by the President of the Republic of Poland upon the advice of the Minister of Justice presented with the consent of the Prime Minister ${ }^{22}$ ) from among the persons who occupied the position of judges or prosecutors for at least five years. Their deputies were appointed by the general assembly of the court of appeal. ${ }^{23}$ In terms of their official position, they were made equal with other judges of the court of appeal. The purpose of appointing this institution was to make it possible to concentrate inquiries concerning more serious crimes, which were committed in several districts, in the hands of one examining magistrate, who was more experienced, as well as to have inquiries conducted by a magistrate "stojący $\mathrm{z}$ dala od stosunków lokalnych" [who was far removed from the local relations]. ${ }^{24}$

${ }^{20}$ The law on the system of common courts of the $6^{\text {th }}$ of February 1928 (Journal of Laws 1928 , No. 12 , item 93).

${ }^{21}$ The regulation of the President of the Republic of Poland of the $15^{\text {th }}$ of July 1927 on the examining magistrates for cases of exceptional importance (Journal of Laws 1927, No. 69, item 611).

${ }^{22}$ The regulation of the President of the Republic of Poland of the $7^{\text {th }}$ of October 1932, which changed certain provisions of the Law on the system of common courts, introduced a uniform principle in relation to appointing all judges - appointing them by the President of the Republic of Poland upon the advice of the Minister of Justice presented with the consent of the Prime Minister (Journal of Laws 1932, No. 86, item 734).

${ }^{23} \S 18$ item 3 of the General regulation concerning the internal operation of courts of appeal, district courts, and municipal courts (Journal of Laws 1928, No. 104, item 934).

${ }^{24} Z$ nowego ustroju sądów powszechnych. Streszczenie i omówienie przepisów o ustroju sądów powszechnych ze szczególowym uwzględnieniem przepisów o sądach pracy przez $d r J$. Wz. [From the new system of common courts. A summary and discussion on the provisions on the system of common courts with special attention paid to the provisions on the industrial tribunal by J. Wz., PhD], Cracow 1929, pp. 29-30. 
The examining magistrates for cases of exceptional importance undertook the conducting of an inquiry following a resolution of the Supreme Court, which was made upon the motion of the Minister of Justice as the Public Prosecutor General, or following a resolution of the Court of Appeal, which was made upon the motion of the prosecutor at the Court of Appeal. The prosecutor delegated by the Minister of Justice, or the prosecutor at the Court of Appeal or their deputy performed prosecutorial supervision of the activities carried out by them. A district court which was working in the seat of an examining magistrate for cases of exceptional importance constituted a higher instance institution.

Appointing the institution of the examining magistrates for cases of exceptional importance was criticized in the doctrine. Among the raised issues was the fact that its creation generated suppositions that cases were not treated with equal attention in court: some were considered more important and given to the examining magistrates for cases of exceptional importance, while others - which were considered less important - were handed to the "regular" examining magistrates. One matter was considered to be an exceptional shortcoming, namely a lack of a precise statutory delineation pertaining to which cases were to be considered cases of exceptional importance. This, in turn, resulted in an unwanted freedom for the organs of the justice system. ${ }^{25}$

The examining magistrates who worked in the district courts were district judges. The law on the system of common courts of 1928 formally abolished all differences which were previously present between the judges of a given district court. The hitherto examining magistrates, provided they had the qualifications required of judges (which was not an obvious matter, at least not in case of judges in the Russian Partition), became district judges by virtue of the law which came into force on the $1^{\text {st }}$ of January $1929 .{ }^{26}$ There had to be certain doubts regarding this as it was additionally confirmed later by a ruling of the Supreme Court. ${ }^{27}$ Consequently, their position in the hierarchy of the positions in the judiciary was firmed up and it was done so on a higher level than previously. Even though the formal status of the examining magistrates was made equal with the status of other judges of this court, they remained separate in respect to the difference in the function they performed. Moreover, their function, which consisted in conducting

${ }^{25}$ Ibidem, pp. 118-119.

${ }^{26}$ Article $280 \S 2$ of the Law on the system of common courts.

27 The Supreme Court ruling of the $12^{\text {th }}$ of November 1929 [in:] Z. Nagórski, Prawo o ustroju sądów powszechnych z dn. 6 lutego 1928 wedlug jednolitego tekstu z dn. 5 listopada wraz z ustawami i rozporzadzeniami zwiazkowymi $i$ wykonawczymi oraz orzecznictwem Sadu Najwyższego [The law on the system of common courts of the $6^{\text {th }}$ of February 1928 according to the uniform text of the $5^{\text {th }}$ of November together with the union and executive acts and regulations as well as with the judicial decisions of the Supreme Court], Warsaw 1933, p. 9. 
acts of inquiry, was designated already at the time of their appointment and not by the general assembly of a given district court. ${ }^{28}$ However, in practice, contrary to the legal regulations, much more serious differences remained even though they were in accordance with the interpretation of the Ministry of Justice. ${ }^{29}$ The differences mainly pertained to the remuneration which the examining magistrates were supposed to be formally entitled to according to the same category as the district judges but, in reality, it belonged to one of the lower categories. ${ }^{30}$

The number of examining magistrates was determined for each district court by the Minister of Justice. If it was necessary, the Minister also could designate the location of their seats outside the seat of a given district court. ${ }^{31}$ Moreover, it was formally in the purview of the Minister of Justice to abolish the examining magistrates' positions. However, due to the fact that examining magistrates were district judges at the same time, they remained district judges even after the position was liquidated (as this position could not be abolished independently by the Minister of Justice). And so, by virtue of the binding law, they were to be transferred to one of the court's departments in accordance with the resolution of the general assembly of the court. ${ }^{32}$ It was a formal confirmation of the principle of equality of the examining magistrates with other district judges. However, a different practice was formed in this area due to the interpretation by the Ministry of Justice..$^{33}$ To be more precise, transferring from the category of examining magistrates to the category of district judges and vice versa took place in the following manner - a candidate was chosen each time by the general assembly of the court and then they were appointed again by the President of the Republic of Poland. ${ }^{34}$ The regulation of the $23^{\text {rd }}$ of August 1932, which was an amendment to the Law

${ }^{28}$ A. Goldman, "Redukcja" sędziów śledczych w świetle przepisów prawa ["Reduction" of examining magistrates in the light of the provisions of law], "Gazeta Sądowa Warszawska" [The Warsaw Court Gazette] 1932, issue 27, p. 375.

${ }^{29}$ Article $57 \S 3$ of the Law on the system of common courts.

${ }^{30}$ N. Dąbrowicki, Jeszcze o uposażeniu sędziów okręgowych śledczych [More on the salaries of examining district magistrates], "Głos Sądownictwa" [The Voice of the Judiciary] 1931, issue 5, pp. 282-285.

${ }^{31}$ Article 5 of the Law on the system of common courts.

$32 \S 17$ item 2 of the General regulation concerning the internal operation of the courts of appeal, district courts, and municipal courts (Journal of Laws 1928, No. 104, item 934). See also W. Wiszniewski, O trybie zwijania stanowisk sędziów okręgowych śledczych [The procedure of liquidating the positions of examining district magistrates], "Głos Sądownictwa" [The Voice of the Judiciary] 1930, issues 7/8, pp. 443-445.

33 W. Nestorowicz, Odmęty interpretacyjne [Interpretational maelstrom], "Głos Sądownictwa" [The Voice of the Judiciary] 1931, issue 4, pp. 218-221.

${ }^{34}$ W. Chmielarz, Wybieranie sędziów okręgowych śledczych na stanowisko sędziów okręgowych [Selecting examining district magistrates for the position of district judges], "Głos Sądownictwa" [The Voice of the Judiciary] 1929, issue 4, pp. 176-177. 
on the system of common courts of 1928, introduced - in case the position of the examining magistrate was abolished in a given town - the possibility of designating a different seat to the person performing these duties on the territory of a given district court without any change in the performed function. ${ }^{35}$

The issue of the reduction of the positions of examining magistrates was extremely emotive, especially the manner in which it was carried out in practice. There was complete freedom in the judicial administration due to a lack of precise secondary legislation, which would indicate the criteria deciding whether a given magistrate should be stripped of the inquiry functions. In certain cases, professional seniority in general was the deciding factor, while in other cases service duration at a given court decided; it should be noted that this seniority could result in a magistrate remaining at his duties but the result was quite opposite in other cases - seniority, especially when it gave the right to an early retirement, caused a person to be removed from the position and a younger one was installed instead. Other factors sometimes played a major role. ${ }^{36}$

The total number of examining magistrates oscillated between 142 (in 1936) and 247 (in 1929). In the following years, the number equalled: in $1928-241$ examining magistrates, in $1929-247$, in $1930-231$, in $1932-161$, in $1934-210$, in $1936-142$, in $1937-171$. The largest number of examining magistrates was in the Warsaw appeal district and there were also many of them in the appeal districts in Lublin and Vilnius, while the smallest number was in Cracow, Poznań, and Torun. For instance, the 231 examining magistrates in 1930 were divided in the following manner between the different appeal districts: Warsaw -89 examining magistrates, Lublin - 48, Vilnius - 46, Lviv - 25, Katowice - 11, Poznań - 6, Torun -4 , and Cracow -2.37

The practice of the Ministry of Justice concerning the appointment of persons for the function of examining magistrates consisted in frequently entrusting it to people with small professional experience, and sometimes even to assessors. It was not conducive to creating a proper relation between examining magistrate, prosecutors, and the police, who all were organs which cooperated during the preliminary procedure. Young, inexperienced magistrates frequently could not inspire authority which was due to their position. ${ }^{38}$

${ }^{35}$ Regulation of the President of the Republic of Poland of the $23^{\text {rd }}$ of August 1932 changing some of the provisions of the Law of the system of common courts (Journal of Laws 1932, No. 73, item 661).

${ }^{36}$ A. Goldman, "Redukcja”... [“Reduction"...], p. 375.

37 J. Szarycz, Sędziowie $i$ sady w Polsce w latach 1918-1988 [The judges and courts in Poland between 1918 and 1988], Warsaw 1988, pp. 22-23.

${ }^{38}$ S. Waltoś, Sędzia śledczy... [The examining magistrate...], p. 19. 
In light of the Code of Criminal Procedure of 1928, the main duty of examining magistrates and magistrates for cases of exceptional importance was to conduct inquiries. Certain actions were also provided for them in the course of the investigations conducted by the prosecution or by the police. Occasionally, in accordance with the system provisions, they also could be appointed to complete the composition of the court and it meant performing a different function, namely that of adjudication.

The purpose of an investigation was to arrive at a conclusion whether a crime had been indeed committed, who could be suspected of committing it, and were there sufficient grounds for a prosecutor to instigate court proceedings (article 243 $\S 1$ of the Code of Criminal Procedure). Court activities were carried out by an examining magistrate or by the municipal court during an investigation. The choice of the proper entity belonged to whoever was to conduct the investigation, i.e. to the prosecution or to the police. The activities included: interrogating suspects; interrogating a witness under oath if there were concerns that the witness may not be able to appear at the main trial or that the witness would not tell the truth without swearing the oath; examining the mental state of the suspect as well as undertaking steps to determine physical evidence if there were concerns that it would not be possible to recreate the evidence without reading out the report concerning this activity during the main trial (article 251 of the Code of Criminal Procedure). After the amendments were made to the Code of Criminal Procedure in 1932, the catalogue of these activities was expanded to include, among others, interrogating witnesses of the victim, persons who apprehended or brought in a suspect as well as interrogating witnesses who lived outside the district of a given district court. ${ }^{39}$ Consequently, the powers of examining magistrates and of the municipal courts which were a part of the investigation mainly pertained to securing evidence in a procedural manner for the adjudicating court. In emergencies, i.e. when the magistrate was not present at the scene of a crime and a delay could result in the disappearance of traces or evidence of the crime, some of these court activities could have been undertaken by the prosecutor or by the police. However, examining the mental state of a suspect was not among them. The right to deputize for the organs of the court by the prosecution or by the police in court activities was particularly criticized. ${ }^{40}$ Inquiries were procedures conducted by the examining magistrates, the examining magistrates for cases of exceptional importance, or -

39 The act of the $21^{\text {st }}$ January 1932 changing some provisions of the criminal procedure (Journal of Laws 1932, No. 10, item 60).

${ }^{40}$ A. Mogilnicki, Czynności sądowe $w$ toku dochodzenia wedtug k.p.k. i projektu Komisji Kodyfikacyjnej [Court activities in the course of an investigation according to the Code of Criminal Procedure and the project of the Codification Committee], "Gazeta Sądowa Warszawska" [The Warsaw Court Gazette] 1929, issue 49, pp. 733-737. 
in cases when they were conducted outside the seat of the district court - by the municipal court (article 258 of the Code of Criminal Procedure). It was only instigated in cases belonging to the jurisdiction of a district court in the first instance and its purpose was a comprehensive explanation of the circumstances of the case and providing the public prosecutor with the necessary information concerning the validity of initiating court proceedings or discontinuing proceedings as well as preserving evidence for the sentencing court (article 259 of the Code of Criminal Procedure). Initiating an inquiry took place upon the motion of the prosecution or upon the motion of the suspect. If the examining magistrate did not agree with the prosecutor's motion, then they presented the case to the district court to decide and only activities which could not be delayed were undertaken (article 262 of the Code of Criminal Procedure). However, when the motion to initiate an inquiry was made by the suspect, then they could independently make a decision whether to initiate an inquiry or to dismiss the motion. All the decisions of the examining magistrate and of the district court concerning initiating inquiries were subject to lodging an appeal in the form of a complaint (articles 262-264 of the Code of Criminal Procedure).

Magistrates were duty bound to immediately interrogate suspects (unless they were interrogated earlier according to article 168, for example by another examining magistrate, after they were brought in after they had been apprehended) and issue a decision to put the suspect on remand within 24 hours (article 265 of the Code of Criminal Procedure). If the suspect was already in jail, and the magistrate decided there were no grounds for it, then it was their duty to release the suspect without delay. ${ }^{41}$ In the course of an inquiry, examining magistrates undertook all possible actions on their own initiative and among them were: interrogating witnesses under oath; examining the circumstances of the case by interrogating witnesses, expert witnesses, conducting inspections or searches; making decisions concerning forfeiture of bail money or collecting the bail; allowing sides and their counsels to review the case files and to make authenticated copies, even though the sides had the right to make motions to the magistrates. The magistrate's independence was restricted by all legal motions of the prosecution, among which were included practically all motions provided for in the act, for instance motions: to carry out evidence activities, to acquire consent to review the files, to take the oath of witnesses, to overrule or to soften preventive measures, and others ${ }^{42}$ The prosecutor had the right to participate in all acts of inquiry, while the examining

${ }^{41}$ E. Wiśniewski, Sporne kwestie z zakresu śledztwa [Contentious issues in the area of the inquiry], "Głos Sądownictwa” [The Voice of the Judiciary] 1931, issue 5, p. 276.

${ }^{42} \mathrm{~K}$. Eichstaedt, Rola sądu w postępowaniu przygotowawczym a instytucja sędziego śledczego [The role of the court in the preliminary procedure and the institution of the examining magistrate], Warsaw 2009, p. 61. 
magistrate had the right to make decisions concerning the presence of the sides (article 268 of the Code of Criminal Procedure).

If examining magistrates determined there were no grounds to suppose that the continuation of the inquiry could provide grounds for the main trial, then they informed the prosecutor about it; however, they did not have the competence to dismiss the proceedings themselves (article 271 of the Code of Criminal Procedure). On the other hand, they had the right to dismiss the inquiry if auxiliary prosecutors or private prosecutors demanded it or agreed to it as well as on demand or with the consent of the prosecution (article 272 of the Code of Criminal Procedure). Later, after the amendments introduced in 1932, they had to dismiss the inquiry obligatorily if the prosecutor demanded it. After deciding that the inquiry had already provided grounds for the main trial, the examining magistrate made the decision to close it.

IV. The Code of Criminal Procedure was amended many times since it had come into force and these amendments pertained also to the institution of the examining magistrate. There was only one direction of these changes: increasing the powers of the prosecutor and simultaneously decreasing the powers of the magistrate. In effect, two entities competed in the inquiry, the examining magistrate and the prosecutor, which influenced its course by delaying it and making it longer unnecessarily, and sometimes even by taking away the factual sense from the examining magistrate's actions. Because in practice, after receiving a notification of committing a crime, the prosecutor as a rule did not transfer the case directly to the examining magistrate but they conducted an investigation themselves with the aim of clarifying whether a crime had been committed, who could be suspected of committing it as well as if there were grounds to initiate court proceedings. As a consequence, already at this stage of the proceedings, the prosecution had to decide whether there were grounds to assign a punishable act to a particular person. In order to be able to ascertain it, the prosecutor had at their disposal many legal options, which in principle were similar to the powers of the examining magistrate in the course of an inquiry. ${ }^{43}$

The practice of conducting inquiries was far from perfect. Examining magistrates received too many cases and, as a result, some of them had to wait for a long time before they were undertaken. In turn, this caused the results of such dragged out or postponed inquiries to be scant. Additionally, young and inexperienced judges and assessors, who often performed the functions of examining magistrates, did not constitute a guarantee that the inquiries would be carried out properly. They did not possess professional experience, including special qualifi-

${ }^{43}$ A. Eimer, O nowy ustrój Prokuratury [For the new system of the prosecution], "Głos Sądownictwa" [The Voice of the Judiciary] 1935, issue 10, pp. 710-711. 
cations to conduct difficult and complicated inquiries, but they even lacked normal life experience, which was also very useful to carry out such duties. ${ }^{44}$ Examining magistrates were so taxed by their workload that circular letters calling for decreasing the number of inquiries were even issued in individual court districts. ${ }^{45}$

$\mathbf{V}$. The discussion concerning the institution of the examining magistrates as well as the model of the preliminary procedure became heated in legal environments only under the rule of the unified law. There were not many comments in the professional press previously and they mainly pertained to the interpretations of the provisions in force and not to their detailed analysis. This probably stemmed from considering the postpartitioning legal situation as temporary and concentrating on following the work on the uniform law. Finally, however, the adopted solutions did not satisfy anyone, neither the theorists nor the legal practitioners (the judges and the prosecutors were also included in the latter group), which resulted in them being widely criticised and there were even bigger waves of criticism starting from the middle of the thirties.

An essential contentious issue in the interwar doctrine was the issue of the validity of existence of the institution of the examining magistrate. A large number of people advocated the theory which considered that this institution was superfluous in the criminal procedure. Perhaps the main source was of this opinion was its imperfect legal form. The proponents of abolishing the institution of the examining magistrate postulated transmitting the entire preliminary procedure into the hands of the prosecutor. It was mainly advocated by the principle stating that the prosecutor takes the responsibility for indicting a particular person and, as a consequence, they should personally undertake all activities to ascertain the actual and legal state of a case. It was argued that only gathering all these competences in one hand could guarantee an accurate evaluation of the circumstances of the case and the validity of a possible indictment. The prosecutor preparing the indictment should not only be acquainted with the case through the files prepared by the court organs but directly through their own actions. ${ }^{46}$ In this situation, the role of the court was to be limited only to passing sentences, while the institution of the examining magistrate was becoming obsolete. ${ }^{47}$ It was emphasized that this concept had obvious advantages: removing the harm-

${ }^{44}$ S. Lipień, Czy sędzia śledczy jest jeszcze potrzebny? [Is the examining magistrate still necessary?], "Głos Sądownictwa" [The Voice of the Judicary] 1936, issue 2, p. 135.

${ }_{45}$ J. Wayzner, Przygotowawcze postępowanie karne w praktyce [The criminal preliminary procedure in practice], "Głos Sądownictwa" [The Voice of the Judiciary] 1935, issue 6, p. 434.

${ }^{46}$ A. Eimer, Prokurator czy sędzia śledczy [The prosecutor or the examining magistrate], "Głos Sądownictwa” [The Voice of the Judiciary] 1936, issue 5, pp. 390-391.

47 A. Eimer, O nowy ustrój... [For the new system...], "Głos Sądownictwa" [The Voice of the Judiciary] 1935, issue 10, pp. 710-712. 
ful competition between the examining magistrate and the prosecution, abolishing the faulty institution of the inquiry as well as bringing the prosecutor closer to the society. This last factor was particularly accentuated as one of special importance from the point of view of the best interest of the society. It was even suggested that prosecutors who possessed expanded powers should be assigned a registered office outside of the seat of the prosecutor's office. The purpose of this was to facilitate the local population's access to the prosecutor which was supposed to lead to the creation of an actual contact between the prosecutor and the citizens. It was simultaneously postulated that the prosecutor's tasks connected with general prevention should increase.

The view that the legislator divided the functions which made up one preliminary procedure between the prosecutor and the examining magistrate was frequent. The reason behind this was the opinion that the legislator was distrustful of one of these two entities, namely of the prosecutor. That is why the legislator strived to limit their competences and transferred many of their competences to the examining magistrate. However, it was emphasized that the law on the system of common courts of 1928 did not make any major distinction between the representatives of these two legal professions in regard to their professional preparation and the requirements of the professional ethics. The same studies were required and the same legal apprenticeship had to be completed. Moreover, it was even allowed to more or less freely move from one of these professions to the other. The arguments against the opinion that considered the prosecutor to be less objective than the magistrate indicated that the prosecutor's actions were not only directed at bringing forth an indictment against the suspect, as their role did not end when the indictment was prepared. It continued in the course of the court proceedings when their statements were evaluated by the court and by the society if the case was not conducted at closed sessions. The following was stated:

Żaden oskarżyciel publiczny nie ma interesu w tym, aby narażać się na ciężki zarzut, iż zniekształca rzeczywisty obraz wydarzeń, przy tym możność wysnuwania z nich jednostronnych wniosków jest nader ograniczona. Jak wyglądałby wobec społeczeństwa i władzy przełożonej stróż praw, któryby wniósł niesłuszne oskarżenie i przekręcił fakty? [No public prosecutor has any interest in facing the heavy accusation of distorting the actual picture of events and simultaneously the possibility of coming to one-sided conclusions is extremely limited. How would a peace officer look in the eyes of the society or of the superior authority if they made an unfair indictment and twisted the facts?]. ${ }^{48}$

${ }^{48}$ H. Chutkiewicz, Kto ma utrwalać materiaty dla procesu karnego? [Who is to record materials for the criminal procedure?], "Głos Sądownictwa" [The Voice of the Judiciary] 1936, issue 5, p. 392. 
Even the fact that the division of acts included in the preliminary procedure was more conducive to irregularities than putting them only in the hands of the prosecutor was raised. The issue of accountability for the course of the preliminary procedure and for its result was not entirely settled. A prosecutor who made an unsubstantiated indictment could, in case the existing model was preserved, shift the responsibility onto the examining magistrate, while if they were to bear the full responsibility for the entire procedure, then they would be more determined to explain the case to the best of their ability because if

[...] nie będzie mógł przerzucić na innych odpowiedzialności za powolność, złe załatwianie lub paczenie sprawy, [...] postara się załatwiać sprawy szybko i dobrze [they could not shift the responsibility onto others for tardiness, conducting the case badly or bungling it, [...] they will attempt to conduct the cases fast and properly]. ${ }^{49}$

However, voices were also raised which advocated preserving the institution of the examining magistrate. Generally, the necessity of its reform was noticed then and sometimes even of an essential reform. As a remedy for the irregularities which occurred in the preliminary procedure, especially in the form of protracted inquiries, strengthening the position of the examining magistrate at the expense of the prosecutor's role was proposed and it was connected with the introduction of a more correct staff policy in the judiciary. The positions of examining magistrates were to be filled by people with the biggest experience and the best professional skills and not by young lawyers, which was the hitherto prevailing method. Their position in the court hierarchy was to be especially strengthened or at least made fully and actually equal with the position of adjudicating judges. These magistrates were supposed to be equipped with all the necessary means to act in a proper and rapid manner, while their hitherto limitations, existing mainly because of the prosecutor, were to be abolished. The magistrate was supposed to independently make decisions concerning the next stages of the inquiry, including finishing it. There was another interesting proposition, namely the project of creating inquiry departments in the district courts, which were to be headed by a separate vice-president or by one that would be shared with the criminal department. The number of examining magistrates was to depend on the current needs, which were naturally changing, which meant the possibility of delegating adjudicating judges to inquiries and vice versa - delegating examining magistrates to adjudicate. The inquiry department was to have its own office with a separate secretary. The vice-president was to acquire constant access into the rational division of the work

49 Ibidem, p. 393. 
in the department, while the examining magistrates were to have the necessary platform for cooperation. ${ }^{50}$

The scope and character of the activities undertaken in the course of the preliminary procedure was also supposed to be a reason why the institution of the examining magistrate should be retained. The difficulty, according to many, in having them completed solely by the prosecution, even when it was supported by the police, was behind this reasoning. The fact that certain activities required particular knowledge and discernment, which was rather the characteristic of the magistrate than of the other organs taking part in this procedure, was also raised:

[...] istnieje [...] wielka grupa spraw, gdzie zbierania materiałów w formie przesłuchiwania świadków, wyszukiwania i badania dowodów rzeczowych, absolutnie nie można powierzyć tak mało wykwalifikowanemu w tym względzie organowi, jakim jest policja państwowa [there exists [...] a great group of cases in which collecting materials in the form of interrogating witnesses, searching for physical evidence and examining them which absolutely cannot be entrusted to an organ with low qualification in this area, which the state police is]. ${ }^{51}$

Even though the prosecutor in professional matters, as it was claimed, was capable of performing these duties with equal success as the examining magistrate, it was inevitably supposed to lead to overburdening them with work. As a result, it would lead to lowering the quality of effects of the preliminary procedure. It was also emphasized that the character of the examining magistrate's work was frequently monotonous and arduous, as it was based on "metodyczne i powolne badanie różnych hipotez, z których jedna w końcu okaże się słuszną" [methodical and sluggish study of various hypotheses from among which one finally turns out to be true], ${ }^{52}$ and it was something completely different from the work of the prosecutor, which was "tocząca się wartką strugą, żywa i wieloraka" [fast-paced, lively, and multi-faceted], ${ }^{53}$ which consisted in the evaluation of the collected material to check the validity of indicting someone as well as in the participation in the latter stages of the court proceedings. And even though, as it was emphasized, it would be beneficial to combine the function of the prosecutor and of the examining magistrate in one person from the economic point of view of the justice system, it would not be beneficial from the point of view of effectiveness. Only

${ }^{50}$ S. Lipień, Czy sędzia śledczy... [Is the examining magistrate...], pp. 135-136.

51 W. Strumieński, Sędzia śledczy czy prokurator [The examining magistrate or the prosecutor], "Głos Sądownictwa" [The Voice of the Judiciary] 1935, issue 11, p. 785.

${ }^{52}$ Ibidem, p. 786.

${ }^{53}$ Ibidem. 
when they functioned separately and performed different procedural roles, the two organs complemented each other excellently.

Finally, the institution of the inquiry itself was criticized as it was considered insufficient to fulfil important social needs. The delayed moment of initiating an inquiry as well as its slow course was evaluated the worst. The dependence of initiating an inquiry on the motion of the prosecutor was considered to be one of the reasons behind the ineffectiveness of the examining magistrate's work as cases were from time to time transferred into their hands too late to properly find and preserve the evidence of the committed crime. This happened due to the fact that the prosecutor waited until they received proper material from the police organs in the form of an investigation in order to make a motion for an inquiry to be initiated. It was emphasized that inquiries preceded by such investigations were limited to a large extent to repeating the acts which had already been carried out in the course of the investigation with the sole difference being, a negative one for the inquiries, that they were conducted much later and so they were not done while "everything was still hot." There were also voices in this matter which claimed that, since the examining magistrate only "reworked" for the second time the material which had already been ascertained in the course of the investigation, it meant that an inquiry was initiated unnecessarily or the examining magistrates conducted it incompentently. ${ }^{54} \mathrm{~A}$ reconstruction of the investigation and of the inquiry was also postulated. It was to be carried out in such a way as to give them an equal chance to complete the tasks of immediately collecting and preserving evidence set before them, without repeating the work, however. It was mainly supposed to lead to making it possible for examining magistrates to collect evidence at the scene of the crime directly after it had been committed and initiating an inquiry independently of the prosecutor's motion. The proposed combination of the function of the examining magistrate with the organs of the investigation department of the police was viewed as a practical and justified solution. This department would be led by an examining magistrate in the course of the conducted acts of inquiry but also during investigations into cases of lesser significance than the ones conducted in the course of an inquiry. Investigations into cases of the smallest importance were to be left to state police stations and precincts. In summary, it was claimed that:

[...] tego rodzaju organizacja dochodzeń i śledztw niewątpliwie bardziej odpowiadałaby nowoczesnym sposobom walki z przestępcami i przestępstwem, dając jednocześnie maksimum pewności nienaruszania nietykalności osobistej, tej podwaliny wolności obywatelskiej, a w związku z reorganizacją instytucji sędziów

${ }^{54}$ J.E. Grabowski, $W$ obronie śledztwa [In defence of the inquiry], "Głos Sądownictwa" [The Voice of the Judiciary] 1935, issue 12, p. 871. 
śledczych i śledztwa jako takiego, wyłoniłaby się potrzeba częściowej również reorganizacji dotychczasowego ustroju tak prokuratur, jak i sądów powszechnych [this type of organization of investigations and inquiries would undoubtedly correspond more to the modern methods of fighting criminals and crime, giving at the same time maximum certainty of bodily inviolability remaining intact, this foundation of civil liberties, and, in connection with the reorganization of the institution of examining magistrates and of inquires as such, there would also appear a need to partially reorganize the hitherto system of both the prosecutor's office and of the common courts]. ${ }^{55}$

VI. Let us try to summarize the comments above. The discussion concerning its validity as well as concerning the scope of functioning of the institution of the examining magistrate was a part of several wide-ranging areas. The first one of them was connected with the postulate of reforming the preliminary procedure, especially making it uniform. As it was emphasized, this procedure had various forms: informal investigations, the so-called simplified procedure, carried out by the police; formal investigations, the so-called prosecutorial investigation; court investigations as well as inquiries. Various combined forms were added to them which from time to time combined different types in one case. According to many, all of this had a negative influence on the course of the procedure. That is the reason behind the repeated postulate of unifying this phase of the criminal procedure. ${ }^{56}$ According to a frequently expressed opinion, the most adverse factor in obtaining the results of the preliminary procedure was the variety of the entities taking part in it, in different scope and on different stages. Consequently, concentrating the entire preliminary procedure in one hand and in one basic form was supposed to guarantee continuity, efficiency, and impartiality in the pursuit of criminals. The prosecution was most frequently considered to be the most suitable organ for this purpose. However, the thesis concerning the necessity of concentrating the preliminary procedure in the hands of the prosecutor was persistently opposed with the view concerning the possibility, and even the need for cooperation between the prosecutor and the examining magistrate for the good of this procedure. Thanks to

55 J. Salewicz, Ustawowa konstrukcja śledztwa w praktyce [The statutory construction of the inquiry in practice], "Głos Sądownictwa" [The Voice of the Judiciary] 1935, issue 2, p. 103.

${ }^{56}$ E. Wiśniewski, Uwagi w sprawie reformy postępowania przygotowawczego karnego [Comments concerning the issue of the reform of the preliminary criminal procedure], "Głos Sacownictwa" [The Voice of the Judiciary] 1936, issue 1, pp. 46-50; M. Hauswirt, S. Popower, Proponowane zmiany śledztwa i dochodzenia $w$ świetle zasad procesowych [The proposed changes in the inquiry and in the investigation in light of the procedural rules], "Archiwum Kryminologiczne" [The Archive of Criminology], Vol. I, issue 2, p. 255 et seq.; J. Kondratowicz, Czy potrzebna jest reforma postepowania przygotowawczego karnego [Is a reform of the preliminary criminal procedure necessary?], “Gazeta Sądowa Warszawska” [The Warsaw Court Gazette] 1935, issues 17/18. 
this cooperation, the detection of the entire material truth, i.e. achieving the main purpose of the procedure, was supposed to be easier.

Czyż można twierdzić, że taka dyskusja dwóch czynników, występujących w śledztwie jest szkodliwa, niepotrzebna, że przeciwnie istnieje potrzeba jednolitości? Zapewne, doraźne efekty może łatwiej osiągnąć jeden człowiek, niż dwóch, ale przecież śledztwo dąży do wykrycia prawdy materialnej, do czego rozważenie danego zagadnienia z różnych punktów widzenia może być tylko korzystne" [Can one claim that such a discussion between the two factors present in the inquiry is harmful, unnecessary, on the contrary, that there exists a need of uniformity? Most assuredly, immediate effects can be more easily achieved by one person rather than by two people, however, an inquiry aims to detect the material truth, and considering a given issue from different points of view can only be beneficial]..$^{57}$

The second important area of discussion pertained to the effectiveness, or to be more precise, the lack of the effectiveness of the inquiry itself in practice. The frequently repeated thesis concerning the slow pace of inquiries was opposed by the argument which mainly indicated the complexity of matters it was the object of as well as the necessity of the examining magistrate personally conducting almost all the acts. A kind of short-term remedy to this phenomenon was supposed to be the betterment of work conducted by the auxiliary organs of the examining magistrate. However, the accusation concerning sluggishness, which was raised, was irrelevant as difficult and complex cases (and inquiries were only initiated in such cases) should not be conducted with haste and inaccuracy. ${ }^{58}$ The blame for delaying an inquiry was usually put on the procedures initiating it, which depended on the prosecutor's motion. However, there were polemics concerning this issue as well. For instance, it was stated that the fact that the prosecutor initiates an inquiry did not necessarily influence the delay of this procedure as the motion could be made over the telephone, which was actually practiced quite often. Also the police, after being informed that a crime had been committed, could and did inform the prosecution of this fact by phone, which significantly accelerated the proceedings. The fact that examining magistrates sometimes repeated some of the actions, which had already been carried out in the course of the investigation, stemmed from the fact that the prosecution only decided there was a need for an inquiry after the investigation had been completed and this was also a justification for some delay in its initiation. Furthermore, it was most frequently the examining magistrate's task to explain such circumstances of a case which required carrying

\footnotetext{
57 J.E. Grabowski, Wobronie... [In defence...], p. 870.

${ }^{58}$ Ibidem, p. 871.
} 
out a number of court activities backed by legal knowledge. However, the activities did not necessarily require great haste; for instance, promptness was not needed in obtaining an expert opinion concerning physical evidence..$^{59}$

The views concerning the need for the functioning of the institution of the examining magistrate and of the inquiry were diametrically different in Europe. They ranged from the conviction that these institutions were indispensible to claims stating that they were groundless or even harmful. There were also voices which claimed that they were achievements of legal civilization as well as an expression of high culture of the legislation and legal system as they guaranteed personal liberty of the accused and the dignity of the justice system because they prevented the initiation of the procedures without sufficient grounds. It was emphasized that the inquiry is an indispensible preliminary factor to judge a crime and a criminal and even that it was "dusza procesu" [the soul of the procedure] as it gave it shape and form, provided the means to uncover the truth, influenced the course of the proceedings and of the adjudication. It also provided all the necessary safeguards to complete the mission of justice at the same time. It was simultaneously emphasized that examining magistrates had to be excellently prepared to perform this extremely important function as all the mistakes and dereliction of duty on their part constituted a danger for the most important interests of the citizens. However, there were also voices claiming that the inquiry is "zabytek" [a relict] of the old procedure, which brought with it numerous negative consequences. Among them were: wasting time and resources, creating an artificial division of responsibility between the prosecutor and the examining magistrate, depriving the main trial of independence and freshness, and restricting the rights of the accused.$^{60}$ In Poland, as it is evident from the described discussion above, the majority of positions on the topic were placed in the middle, which did not generally reject the institution of the examining magistrate or of the inquiry itself but they rather postulated a deep and sensible change. The change was mainly to consist in a more proper placement of the prosecutor and of the examining magistrate in relation to one another. In this situation, the examining magistrate would not be deprived of the liberty to make decisions, while the prosecutor would be forced to impose certain specified actions on them. ${ }^{61}$

Many of the arguments which were appearing in the course of this interwar discussion concerning the validity as well as the shape of the institution of the

59 J. Wayzner, Przygotowawcze postępowanie karne... [The criminal preliminary procedure...], pp. 433-434.

${ }^{60} \mathrm{~W}$. Nestorowicz, Różne poglady na potrzebę śledztwa [Different opinions on the need of the inquiry], "Głos Sądownictwa" [The Voice of the Judiciary] 1933, issue 5, pp. 13-17.

${ }^{61}$ J.E. Grabowski, W obronie... [In defence...], p. 871. 
examining magistrate are expressed even today. ${ }^{62}$ A number of doubts which have been born during the century remain current until now and so they have not been solved in a satisfactory manner. However, the present-day discussion concerning the institution of the examining magistrate concentrates more on the model of the criminal procedure, especially its preliminary phase, rather than on the subject matter of the examining magistrate. Only answers to the questions concerning the shape of the preliminary procedure as well as the relation between the preliminary procedure and the court proceedings can make a formulation of further conclusions concerning, among others, the institution of the examining magistrate possible, namely: is there a place for it in this procedure, and if so, what is it?

${ }^{62}$ Nowy model postępowania przygotowawczego - sędzia śledczy. Konferencja... [A new model of the preliminary procedure - the examining magistrate. A conference...], Warsaw 2010. 